\title{
ТРАНСФОРМАЦИЯ БОЛЬШИХ СОЦИАЛЬНЫХ ГРУПП В СОВРЕМЕННЫХ УСЛОВИЯХ РАЗВИТИЯ ОБЩЕСТВА
}

\author{
Д.А. Китова, \\ B.A. Соснин \\ Институт психологии РАН
}

\begin{abstract}
Аннотация: В условиях развития информационных коммуникаций большие сочиальные группы оказались подвержены значительным трансформачиям, которые требуют некоторого переосмысления классических концепций. Новым видом социальных групп стали виртуальные группы, устойчивое существование которых обусловлено наличием общих интересов, совместно выработанных иелей и организованных действий по их достижению. С кония ХХ и начала XXI вв. возникли и глобальные групповые образования, которые также обладают рядом специфических психологических характеристик. Активные, саморазвивающиеся большие сочиальные группы способны к саморефлексии и рефлексии и могут выступать основой перспективного развития общества. Представленное предположение требует дальнейшего теоретического осмысления $и$ эмпирического изучения в рамках сочиальной психологии.
\end{abstract}

Ключевые слова: сочиальная психология, большие сочиальные группы, трансформачия, общность, сообщества, общество, глобальные группь

\section{TRANSFORMATION OF LARGE SOCIAL GROUPS IN MODERN CONDITIONS OF SOCIETY DEVELOPMENT}

\author{
D. A. Kitova, \\ V. A. Sosnin \\ Institute of Psychology, Russian Academy of Sciences
}

\begin{abstract}
In the context of the development of information communications, large social groups have been subjected to significant transformations that require some rethinking of classical concepts. Virtual groups have become a new type of social group. their stable existence is determined by the presence of common interests, jointly developed goals, and organized actions to achieve them. Since the late twentieth and early twenty-FIRST centuries, global group formations have also emerged, which also have a number of specific psychological characteristics. Active, self-developing large social groups are capable of self-reflection and reflection and can serve as the basis for the long-term development of society. The presented assumption requires further theoretical understanding and empirical study in the framework of social psychology.

Keywords: social psychology, large social groups, transformation, community, communities, society, global groups

Объектом изучения в социальной психологии, как известно, являются: личность, малые и большие социальные группы. Понятие общности, являясь ключевым в социальных науках и в социальной психологии, отражает потребность людей жить и чувствовать свое единство, солидарность (Почебут, 2002). Но на современном этапе развития цивилизации происходит серьезная трансформация групповых образований, способов и технологий их взаимодействия, которые требуют некоторого переосмысления классических концепций.
\end{abstract}


В социальной психологии сложился определенный тезаурус в определении типологии групповых образований, хотя эти термины используются в разных контекстах и часто недостаточно дифференцируются. Если сделать акцент на больших социальных группах, то изначально они определялись как массовое скопление большого числа людей в одном месте (Arbon, 2004), и чаще всего назывались толпой - случайной, конвенциональной, экспрессивной, экстатической и т.д. Давали определение и с акцентуацией на состояние толпы - действующая (агрессивная, паническая, стяжательная, повстанческая и т.д.). В свою очередь, участникам такого рода образований приписывали ряд специфических психологических признаков: снижение критичности и сознательности в поведении, стремление к немедленному действию, импульсивность и подверженность «психическому заражению» (Лебон, 2006: 11-45).

Второй тип больших социальных групп, который стал рассматриваться несколько позже, это психологические общности людей, характеризующиеся коллективной идентичностью и обладающие групповой психикой. Под большой социальной группой стала трактоваться «реальная, значительная по размерам и организованная общность людей, члены которой вовлечены в ту или иную совместную общественную деятельность» (Психологический словарь, 2007: 73). Эту группу можно определить, как количественно не ограниченную социальную общность, имеющую устойчивые ценности, нормы поведения и социально-регулятивные механизмы. В качестве примера можно указать на национальные, территориальные, семейные, учебные, профессиональные и общественно-политические общности людей (Соснин и др., 2014; и др.).

В самом общем виде такие большие социальные группы определяются как «коллективы индивидов, взаимодействующих между собой и формирующих социальные отношения» (Аберкромби, 2004: 97) или как «...группы людей, в которой общность общественно значимых черт выражается в коллективной идентичности и сопровождающих ее контактах» (Штомпка, 2005: 49). Отмечается, что взаимодействия, проявляющиеся внутри этой группы более интенсивны, чем среди людей, находящихся вне данной группы. К такого рода группам можно отнести социальные слои, этнические, гендерные и возрастные группы и т.д. В научной литературе подчеркивается, что в основе поведения такого рода групп лежат социальные стереотипы, социальная память, социальная идентичность, a ее члены могут не иметь непосредственных контактов между собой, связаны опосредованно психологическими механизмами групповой коммуникации, но, «именно этот тип групп определяет ход истории» (Донцов, 1997).

Еще более высоким уровнем объединения больших социальных групп является общество в целом, существующее в рамках конкретных государственных границ. Важными психологическими механизмами, характеризующими психологию общества, как исторически сложившейся социальной группы, являются об- 
щественное мнение, групповая идентичность, элементы ценностно-нормативной системы общества (обычаи, традиции, нравы, мораль). Общество, как групповое образование, обладает относительно устойчивой системой социальных структур, функций и связей, а мотивами совместной жизнедеятельности выступает стремление сохранять свой суверенитет (социальный, политический, исторический, экономический и т.д.).

Одной из важных интегративных психологических характеристик общества выступает менталитет, который определяется как «система... психической жизни людей, принадлежащих к конкретной культуре... и проявляющейся в поведенческой активности» Кондратьев, Ильин, 2007: 32). Для характеристики психического склада этнических групп используется термин «национальный характер». Тем не менее, «говоря о национальном характере, одни авторы подразумевают прежде всего темперамент, другие обращают внимание на личностные черты людей, третьи на ценностные ориентации, отношение к власти, труду и т.п.» (Стефаненко, 1999: 14). В последнее время для характеристики данного психического феномена чаще используется категория «ментальность», которая считается более строгой и определяется как система образов, которые лежат в основе человеческих представлений о мире и о своем месте в этом мире (там же), но единого толкования менталитета в современной науке еще не сложилось. В качестве составных элементов менталитета можно рассматривать выделенные С. Московичи (Moscovici) социальные представления, под которыми понимаются обыденные представления какой-либо группы о тех или иных социальных явлениях, выступающие способом интерпретации и осмысления повседневной реальности (Донцов, Емельянова, 1987).

Новым видом социальных групп (в том числе и больших), возникшим благодаря развитию интернет-сервисов, стали виртуальные группы (сообщества). В научной литературе выделяют следующие их особенности: трансцендентность (выход за пределы ограничений); наличие внутригрупповой информационной стратификации; высокая степень анонимности; отсутствие формальных ограничений по количеству участников (Сундиев, Смирнов, 2016: 11-21). Как отмечает Н.С. Чураева, «формирование и устойчивое существование виртуального сообщества как социальной группы возможно только при наличии у участников сетевого ресурса общих интересов, совместно выработанных целей и организованных действий по их достижению, которые реализуются в рамках единого коммуникативного пространства» (Чураева, 2009: 7), что соответствует классическим концепциям развития больших социальных групп.

С конца XX и начала XXI вв. возникли глобальные групповые образования, которые не вписываются в традиционные описания больших социальных групп.

Первое место в иерархии глобальных групп, по-видимому, следует отдать транснациональным компаниям (ТК), которые, как глобальные образования, ста- 
ли занимать главенствующую роль в международной политике и экономике. Например, общая выручка американской транснациональной корпорации Google (международный конгломерат Alphabet) за 2019 г. достигла \$161,8 млрд., что превышает государственный бюджет таких стран, как Исландия, Гватемала или Болгария, и опережает ВВП самых бедных 33 стран в совокупности. Доминирующим мотивом деятельности ТК выступает получение прибыли, с политической позиции это связано с игнорированием границ национальных государств.

Следующим глобальным образованием является блок государств. К блоку государств с коллективистическим культурно-ценностным типом относятся геополитический и экономический союзы России, Белоруссии и Казахстана, а также - БРИКС, ШОС и т.д., а к типу государств западной ориентации с индивидуалистическим культурно-ценностным типом - США, ЕС. Они продолжают традиции национальных государств и ориентируются на собственные /совместные национальные интересы, сохранение своего суверенитета и своих социокультурных ценностей и ведут перманентную борьбу за лидерство с другими аналогичными объединениями.

Таким образом, можно выделить следующие базовые концепты по силе и организованности социальных взаимосвязей внутри группы и их значимости для будущего психологического анализа: общество; глобальные групповые образования/объединения; транснациональные компании; блоки государств; массовые объединения (формализованные $(\mathrm{OOH})$, неформализованные общности (Greenpeace), стихийные (протестные или досуговые - спортивные болельщики, музыкальные фанаты) и естественные, возникающие в ответ на изменяющиеся условия жизнедеятельности). Эти концепты, как представляется, могут служить основой для новых исследований в психологии, требуют дальнейшего осмысления проблематики и приемов определения больших социальных групп, в частности, такого ее направления, как массовые явления.

В рамках психологической теории как общества, так и общности могут быть рассмотрены с позиций не только психологии больших социальных групп (БСГ), но и как коллективные субъекты (Журавлев, 2002, 2008; Журавлев, Емельянова, 2009). Большим социальным группам может быть приписано качество субъектности на основе конкретных признаков - взаимосвязанности членов группы, их совместной активности и саморефлексивности (Журавлев, 2002). В работах последних лет выделяется также признак в значительной степени аккумулирующий то, что подразумевается другими признаками, - способность к саморазвитию, связанному с внутригрупповыми процессами, с осмыслением собственных проблем, потребностей и т.д. (Журавлев, Емельянова, 2009: 8). Однако отнесение этого признака к большим социальным группам является отдельной научной проблемой. В целом, признаками коллективного субъекта, по А.Л. Журавлеву, являются: взаимосвязанность и взаимозависимость индивидов в группе; способ- 
ность проявлять различные формы совместной активности; способность группы к саморефлексии и формирование чувства «мы». Все эти признаки в разной мере могут присутствовать в конкретном коллективном субъекте (группе, сообществе, обществе, глобальных объединениях и т.д.).

В одном из своих значений субъектность больших социальных групп можно рассматривать не только как ресурс психологического благополучия общества, но и как ресурс социального благополучия глобального сообщества (мира) в целом. Активные, саморазвивающиеся большие социальные группы, способные к саморефлексии и рефлексии, т.е. осознающие собственную историю, актуальные условия своего существования и активно взаимодействующие с различными проблемными внутригрупповыми процессами, могут являться основой перспективного развития общества (Макропсихология..., 2009). Хотя и очевидно, что данное предположение требует, как дальнейшего теоретического осмысления, так и эмпирического анализа, и подтверждения групповых/субъектных характеристик.

С теоретической позиции, изучение больших социальных групп, общества или глобальных образований, выделение новых видов и типов, новых критериев субъектности и форм существования является самостоятельной научной проблемой (Журавлев, Емельянова, 2009). С практической позиции, как справедливо отмечает И.Г. Дубов, «повсеместно наблюдаемые стихийные волнения, охватывающие большие массы людей, не позволяют игнорировать изучение динамических процессов, возникающих в подобных группах, и, значит, отказываться от изучения способов целенаправленного воздействия на диффузные большие группы на разных этапах генерируемой ими активности» (Дубов, 2012: 117). С методологических позиций, мощным фактором не только образования и взаимодействия, но и изучения таких групп выступает интернет-пространство, в частности обращение к праксиметрическим методам анализа уже совершенных действий, что позволяет получать информацию в условиях «естественного эксперимента», посредством изучения «цифровых следов» ${ }^{1}$. Все эти направления представляют вызов современной психологической науке, которая на сегодняшний день не располагает достаточным уровнем знаний или компетенций ни в одном из представленных направлений изучения глобальных групповых образований. Все эти вопросы, предположительно, будут рассмотрены в рамках зарождающего научного направления - глобальной психологии, и стоит ожидать, что процесс этот будет довольно продолжительным (Психологические исследования глобальных..., 2018).

Подводя итоги, еще раз кратко сформулируем основные характеристики современной глобальной реальности, которые легли в основу профессиональной рефлексии современной социальной психологии. На рубеже XX-XXI вв. социальные отношения претерпели глубокие трансформации. Изменился и научный

${ }^{1}$ На начало 2020 г. интернетом пользуются более 4,5 млрд. людей, мобильными телефонами - более 5,19 млрд., а аудитория социальных сетей перевалила за отметку в 3,8 млрд. 
смысл понятия «социальная группа», которое трактуется теперь значительно шире, по сравнению с предыдущими историческими периодами. Субъектами современных социальных отношений стали не только крупные и мощные державы, но и различные объединения средних и малых государств, транснациональные корпорации, негосударственные международные организации и большие социальные группы людей, объединенные некоммерческими целями. Вследствие представленных позиций массовое сознание (психологию БСГ) необходимо рассматривать как важный ресурс стратегического развития. Без понимания психологии таких групп (в том числе международных), без учета их психологической природы, направленности и динамики настроений и ожиданий реализация социальных стратегий в современных условиях не даст ожидаемого результата (Китова, Китов, 2018).

Психологические исследования БСГ открывают возможности анализа уровня их социальной активности, новых групповых феноменов, осознания ими своего места в мире, а также новых функций и ролей в обществе, т.е. такой динамики, которая отражает их способность быть субъектами и, следовательно, влиять на состояние всего общества, а, в некотором смысле, возможно, и мира в целом (Cоснин и др., 2017; Китова, 2019). Психологический анализ данного концепта пока далек от полноты и конкретности, однако активные шаги в этом направлении уже предпринимаются.

\section{СПИСОК ЛИТЕРАТУРЫ}

Аберкромби Н. (2004) Социологический словарь / Под ред. С.А. Ерофеева. М.: Экономика.

Донцов А.И. (1997) О понятии «группа» в социальной психологии // Вестник Московского университета. Серия 14. Психология. № 4. С. 17-25.

Донцов А.И., Емельянова Т.П. (1987) Концепция социальных представлений в современной французской психологии. М.: МГУ.

Дубов И.Г. (2012) Психология больших групп как один из важнейших разделов социальной психологии // Психологическая наука и образование. 2012. № 1. URL: https://psyjournals.ru/psyedu_ru/2012/n1/50841.shtml (дата обращения: 01.06.2020).

Журавлев А.Л. (2008) Большие социальные группы как субъекты: возможности исследования // Личность и бытие: субъектный подход: Материалы научной конференции. М.: Институт психологии РАН. С. 312-315.

Журавлев А.Л. (2002) Психология коллективного субъекта // Психология индивидуального и группового субъекта. М.: ПЕР СЭ. С. 51-81.

Журавлев А.Л., Емельянова Т.П. (2009) Психология больших социальных групп как коллективных субъектов // Психологический журнал. Т. 30. № 3. С. 5-15.

Китова Д.А. (2019) Отечественная психология в условиях развития глобальных процессов // Психологический журнал. Т. 40. № 2. С. 128-131. 
Китова Д.А., Китов М.А. (2018) Психологические критерии в структуре моделей государственного управления / Психологические исследования глобальных процессов: предпосылки, тенденции, перспективы (коллективная монография). М.: Институт психологии РАН, 2018. С. 333-350.

Кондратьев М.Ю., Ильин В.А. (2007) Азбука социального психолога-практика. М.: ПЕР СЭ.

Лебон Г. (2006) Психология масс // Психология масс: Хрестоматия / Отв. ред. Д.Я. Райгородский. Самара: БАХРАХ-М.

Макропсихология современного российского общества / Отв. ред. А.Л. Журавлев, А.В. Юревич. М.: Изд-во Институт психологии РАН, 2009.

Почебут Л.Г. (2002) Психология социальных общностей (толпа, социум, этнос). СПб.: СПбГУ, 2002.

Психологические исследования глобальных процессов: предпосылки, тенденции, перспективы (2018) / Отв. ред. А.Л. Журавлев, Д.А. Китова. М.: Изд-во Институт психологии РАН.

Психологический словарь (2007) / Под. общ. ред. А.В. Петровского, М.Г. Ярошевского. М.: Политиздат.

Соснин В.А., Журавлев А.Л., Китова Д.А., Нестик Т.А., Юревич А.В. (2017) Массовое сознание и поведение: тенденции социально-психологических исследований. М.: Институт психологии РАН.

Соснин В.А., Журавлев А.Л., Красников М.А. (2014) Социальная психология. Учебное пособие для студентов вузов. М.: Форум; Инфра-М.

Стефаненко Т.Г. (1999) Этнопсихология. М.: Институт психологии РАН; Академический проект.

Сундиев И.Ю., Смирнов А.А. (2016) Теория и технологии социальной деструкции (на примере «цветных революций») М.: Русский биографический институт, Институт экономических стратегий.

Чураева Н.С. (2009) Социально-психологические механизмы формирования виртуальных сообществ: Автореф. дис. ... канд. психол. наук. М.

Штомпка П. (2005) Социология. Анализ современного общества. М.: Логос.

Arbon P. (2004) The development of conceptual models for mass-gathering health // Perbostial Disast Mtd. № 9. P. 208-212.

Китова Дюжльетта Альбертовна - доктор психологических наук, професcop, ведущий научный сотрудник лаборатории истории психологии и исторической психологии, Федеральное государственное бюджетное учреждение (ФГБУН) Институт психологии РАН. Адрес: 129366, Москва, ул. Ярославская, д.13, корп.1, Институт психологии РАН. Телефон + 7 (977) 312-71-89. E-mail: j-kitova@yandex.ru,

Kitova Dzhuletta Albertovna - Doctor of Psychological Sciences, Professor, Leading Researcher, Laboratory of the History of Psychology and Historical Psychology, Federal State Budgetary Institution Institute of Psychology RAS. Address: 129366, Moscow, 
Yaroslavskaya, st.13, korp. 1, Institute of Psychology RAS. Phone + 7 (977) 312-71-89. E-mail: j-kitova@yandex.ru

Соснин Вячеслав Александрович - кандидат психологических наук, ведущий научный сотрудник, Федеральное государственное бюджетное учреждение (ФГБУН) Институт психологии РАН, 129366, Москва, ул. Ярославская, д.13, корп.1, Институт психологии РАН. Тел: +7 (495) 683-38-09. Эл. адрес: sosninrus@rambler.ru

Sosnin Vyacheslav Aleksandrovich - candidate of psychology, leading researcher, Federal State Budgetary Institution Institute of Psychology RAS. Address: 129366, Moscow, Yaroslavskaya, st.13, korp. 1, Institute of Psychology RAS. Phone +7 (495) 683-38-09. E-mail: sosninrus@rambler.ru 2020. №5. C. 46-53. DOI: https://www.doi.org/10.17805/trudy.2020.5.5 